\title{
Asymptomatic Massive Hypertriglyceridemia in an Octogenarian
}

\author{
Arrigo F.G. Cicero Maria Panagiota Panourgia Simona Nascetti \\ Zina Sangiorgi Antonio Gaddi
}

Atherosclerosis and Metabolism Diseases Study Centre 'G.C. Descovich', Clinical Medicine and Applied Biotechnology Department 'D. Campanacci', University of Bologna, Italy

\section{Key Words}

Massive hypertriglyceridemia. Dyslipidemias .

Epidemiology Elderly people

\begin{abstract}
Objective: To report the case of an 85-year-old man with asymptomatic massive hypertriglyceridemia (MHTG). Clinical Presentation and Intervention: Our case was a non-smoker, healthy 85-year-old Caucasian male, with no excessive alcohol intake and no evidence of an excessive sedentary lifestyle, body mass index $=23.2 \mathrm{~kg} / \mathrm{m}^{2}$, $\mathrm{BP}=125 / 85 \mathrm{~mm} \mathrm{Hg}$ and plasma triglyceride (TG) $>1,000 \mathrm{mg} / \mathrm{dl}$. The MHTG was an incidental finding at the age of 70 . He had no cardiovascular disease, xanthomas, xanthelasmas or keratic precipitate. During the last 15 years, his average TG plasma levels showed a significant variability independent of specific diet treatment and fibrate therapy. Liver ultrasound examination excluded hepatomegaly and fatty degeneration. Carotid artery ultrasound showed only intimal thickening in both carotid bifurcations. Conclusion: In this patient, MHTG had been silent for many years, with no evidence of coronary heart disease and liver fatty degeneration, both typical complications present in MHTG subjects with low high-density lipoprotein. Hence, this case must be considered as a
\end{abstract} rarity.

Copyright @2003S. Karger AG, Basel

\section{Introduction}

Massive hypertriglyceridemias [MHTGs; plasma triglycerides $(\mathrm{TG})>1,000 \mathrm{mg} / \mathrm{dl}$ ] are relatively rare genetic diseases of lipid metabolism (prevalence in population $=$ $0.5 \%$ ). Type I, according to Fredrickson's classification $\left(1 / 10^{-6}\right)$, is caused by lipoprotein-lipase (LPL) and/ or apolipoprotein-CII (ApoCII) deficiency [1]. Type III $\left(1 / 10^{-5}\right)$ is related to an ApoE-linked metabolic defect. Type IV is a common autosomal dominant disease $(1 / 100)$ due to defective lipolysis $[1,2]$ and/or very-lowdensity lipoprotein (VLDL) overproduction [3]. The phenotypic conversion from type IV to type V (attributable to endocrine or nutritional factors) is common. MHTGs are rarely related to other pathologies or iatrogenic factors [4]: the more frequent types in the elderly are diabetes mellitus and nephropathy. The usual MHTG symptoms are abdominal pains, fatty liver degeneration (steatosis), hepatosplenomegaly, cholelithiasis, excess fat in the retina (lipemia retinalis) and tuberous eruptive xanthomas. Main complications are acute pancreatitis and coronary atherosclerosis, particularly in type IV subjects with low plasma high-density lipoprotein (HDL) level [5, 6]. Recent studies attribute an important role to TG in atherogenesis and atherosclerosis-related diseases [7, 8].
Arrigo F.G. Cicero, MD

Atherosclerosis Study Centre 'G.C. Descovich'

Clinical Medicine \& Applied Biotechnology Department 'D. Campanacci'

S. Orsola-Malpighi Hospital, Via Massarenti 9, I-40138 Bologna (Italy)

Tel. +39 3498558017, Fax +39 059762089, E-Mail afgcicero@tiscali.it 


\section{Case Report}

This case report concerns an 85-year-old Caucasian male. MHTG was discovered at the age of 70 during presurgical examination for cholecystectomy. He had no history of cardiovascular disease or familial dyslipidemia. His relatives were long-living (fig. 1): no one from either the father's or the mother's side had diabetes mellitus, cardiovascular disease or severe dyslipidemia. He was a non-smoker, with a body mass index of $23.2 \mathrm{~kg} / \mathrm{m}^{2}$, who imbibed a limited amount of alcohol and led an active physical life. His blood pressure was $125 / 85 \mathrm{~mm} \mathrm{Hg}$ and he had no xanthomas, xanthelasmas or arcus cornealis (gerontoxon). No pathological signs were found during both physical and neurological examinations. Blood samples were taken

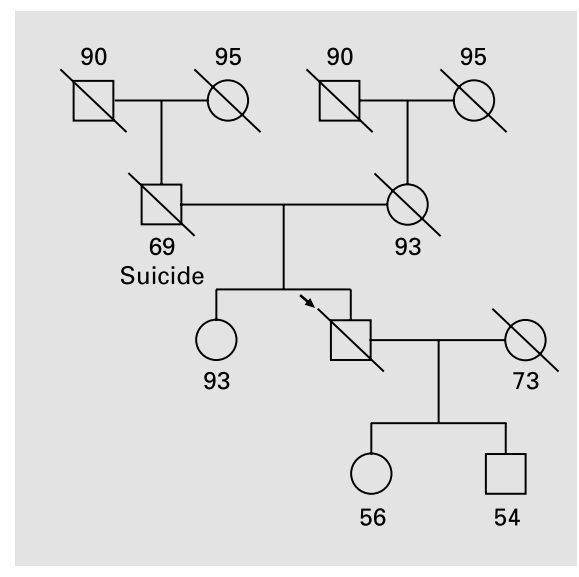

Fig. 1. Propositus' family tree. Boxes = Males, circles $=$ females, $\backslash$ = died, $\backslash$ = propositus, numbers denote the age of death or the actual age. after a 12-hour fasting. Analyses were carried out according to the program for research laboratories specified by the National Reference System for Cholesterol by standard automated methods for lipids and turbimetric methods for apolipoproteins (table 1) [9]. Chylomicron and VLDL plasma detection was carried out after a 24-hour storage at $4^{\circ} \mathrm{C}$ by density gradient ultracentrifugation [10]. VLDL were particularly rich in TG (80-85\%), while LDL and HDL had a normal/high content of 45 and $9 \%$, respectively. During the last 15 years (1970-1985), average plasma levels of his TG varied significantly $(862-3,291 \mathrm{mg} / \mathrm{dl})$ and were independent of appropriate dietetic $(55 \%$ carbohydrates without simple sugars, $20 \%$ proteins, $25 \%$ lipids with an unsaturated/total fatty acid ratio $=0.8 / 1$ ) and pharmacological treatment (fibrates, omega-3 polyunsaturated fatty acids). Natraemia has often been classified as border-line low (138.05 $\pm 0.34 \mathrm{mmol} / \mathrm{l})$. Liver, pancreas and kidney functional parameters were within the normal ranges.

Ultrasound examination of liver and pancreas revealed no abnormalities; hence, hepatosplenomegaly and steatosis/fatty degeneration were excluded. Nephropathies were excluded by the constant monitoring of plasma creatinine and urinary protein levels that were also found to be within the normal range, and routine electrocardiogram results were normal. Diabetes was excluded by finding that $\mathrm{HbA} 1 \mathrm{c}$ plasma levels and postprandial glucose levels had always been in the normal range. Carotid arteries examined with a high-resolution carotid ultrasound method (Biosound, Indianapolis, Ind., USA), capable of detecting minimal lesions in the intimal thickness [11], showed only intimal thickening of $0.9 \pm 0.2 \mathrm{~mm}$ at both carotid bifurcations. The high/normal apolipoprotein $\mathrm{B}(\mathrm{ApoB})$ plasma level combined with the low LDL-C level suggested the presence of small, dense LDL particles that were reminiscent of subnormal intravascular TG hydrolysis. One of the many possible causes of such a profile is partial LPL deficiency caused by a mutation in the LPL gene. The pharmacological resistance to fibrates and diet, typical of subjects suffering from LPL deficiency [6], supported this hypothesis. Unlike other cases described in the literature, it is important to point out that, in this patient, MHTG had been silent for many years and that it had not caused the typical complications present in hypertriglyceri-

Table 1. Propositus plasma lipids, glucose and uric acid pattern; median and range values are evaluated on 9 consecutive bimonthly samples

\begin{tabular}{|c|c|c|c|}
\hline Parameter & Median value & Range & Optimal range \\
\hline TG & $2,243.50 \mathrm{mg} / \mathrm{dl}(25.35 \mathrm{mmol} / \mathrm{l})$ & $862.15-3,291.22 \mathrm{mg} / \mathrm{dl}(9.74-37.18 \mathrm{mmol} / \mathrm{l})$ & $<150(<1.71 \mathrm{mmol} / \mathrm{l})$ \\
\hline $\mathrm{TC}$ & $147.29 \mathrm{mg} / \mathrm{dl} \quad(3.80 \mathrm{mmol} / \mathrm{l})$ & $118.11-191.01 \mathrm{mg} / \mathrm{dl}(3.05-4.93 \mathrm{mmol} / \mathrm{l})$ & $<200 \mathrm{mg} / \mathrm{dl}(<5.16 \mathrm{mmol} / \mathrm{l})$ \\
\hline HDL-C & $21.40 \mathrm{mg} / \mathrm{dl} \quad(0.55 \mathrm{mmol} / \mathrm{l})$ & $12.54-\quad 28.31 \mathrm{mg} / \mathrm{dl}(0.31-0.72 \mathrm{mmol} / \mathrm{l})$ & $>40 \mathrm{mg} / \mathrm{dl}(>1.1 \mathrm{mmol} / \mathrm{l})$ \\
\hline LDL-C & $101.25 \mathrm{mg} / \mathrm{dl} \quad(2.62 \mathrm{mmol} / \mathrm{l})$ & $90.23-119.65 \mathrm{mg} / \mathrm{dl}(2.32-3.07 \mathrm{mmol} / \mathrm{l})$ & $<160 \mathrm{mg} / \mathrm{dl}(<4.13 \mathrm{mmol} / \mathrm{l})$ \\
\hline VLDL-TG & $1,181.28 \mathrm{mg} / \mathrm{dl}(13.35 \mathrm{mmol} / \mathrm{l})$ & $670.06-1,856.87 \mathrm{mg} / \mathrm{dl}(7.57-20.97 \mathrm{mmol} / \mathrm{l})$ & N.D. \\
\hline Chylo-TG & $212.53 \mathrm{mg} / \mathrm{dl} \quad(2.40 \mathrm{mmol} / \mathrm{l})$ & $164.64-291.23 \mathrm{mg} / \mathrm{dl}(1.85-3.29 \mathrm{mmol} / \mathrm{l})$ & N.D. \\
\hline ApoAI & $104.1 \mathrm{mg} / \mathrm{dl} \quad(2.7 \mathrm{mmol} / \mathrm{l})$ & $91.18-115.33 \mathrm{mg} / \mathrm{dl}(2.35-2.97 \mathrm{mmol} / \mathrm{l})$ & $120-160 \mathrm{mg} / \mathrm{dl}(\mathrm{mmol} / \mathrm{l})$ \\
\hline ApoB & $106.9 \mathrm{mg} / \mathrm{dl} \quad(2.8 \mathrm{mmol} / \mathrm{l})$ & $99.41-124.51 \mathrm{mg} / \mathrm{dl}(2.57-3.02 \mathrm{mmol} / \mathrm{l})$ & $70-130 \mathrm{mg} / \mathrm{dl}(\mathrm{mmol} / \mathrm{l})$ \\
\hline Uric acid & $9.39 \mathrm{mg} / \mathrm{dl} \quad(0.56 \mathrm{mmol} / \mathrm{l})$ & $4.11-\quad 19.74 \mathrm{mg} / \mathrm{dl}(0.24-1.17 \mathrm{mmol} / \mathrm{l})$ & $40-70 \mathrm{mg} / \mathrm{dl}(0.247-0.42 \mathrm{mmol} / \mathrm{l})$ \\
\hline Glucose & $98.18 \quad(5.46 \mathrm{mmol} / \mathrm{l})$ & $72.01-111.23 \mathrm{mg} / \mathrm{dl}(4.00-6.17 \mathrm{mmol} / \mathrm{l})$ & $70-125 \mathrm{mg} / \mathrm{dl}(3.9-6.5 \mathrm{mmol} / \mathrm{l})$ \\
\hline HbAlc & $4.9 \%$ & $4.1-5.4 \%$ & $4-\quad 6 \%$ \\
\hline
\end{tabular}

Chylo = Chylomicron; N.D. $=$ not determined . 
demic adults with low HDL. The patient had a healthy medical history except cholecystectomy in old age. It seems noteworthy that his age is included in the $22 \%$ of Italian survivors (data from Italian Statistic Institute) and it coincides with that curve point where life in Italy rapidly decreases. According to recent studies and US guidelines on cardiovascular disease prevention, hypertriglyceridemia could increase cardiovascular risk, especially when associated with low HDL plasma levels $[12,13]$.

\section{Conclusion}

In this patient, MHTG had been silent for many years, with no evidence of coronary heart disease and liver fatty degeneration, both typical complications present in MHTG subjects with low HDL. For these reasons, this case should be considered a rarity.

\section{References}

1 Assmann G, Brewer HB Jr: Genetic (primary) forms of hypertriglyceridemia. Am J Cardiol 1991;68:13A-16A.

2 Ma Y, Liu MS, Chitayat D, Bruin T, Beisiegel U, Benlian P, Foubert L, et al: Recurrent missense mutations at the first and second base of codon Arg243 in human lipoprotein lipase in patients of different ancestries. Hum Mutat 1994;3:52-58.

3 Mancini M, Steiner G, Betterige DJ, Pometta D: Acquired (secondary) forms of hypertriglyceridemia. Am J Cardiol 1991;68:17A-21A.

4 Durrington PN: Hypertriglyceridemia. Hyperlipidemias: Diagnosis and Treatment. New York, McGraw-Hill, 1994, pp 153-174.

5 Piolot A, Nadler F, Cavallero E, Coquard JL, Jacotot B: Prevention of recurrent acute pancreatitis in patients with severe hypertriglyceridemia: Value of regular plasmapheresis. Pancreas 1996;13:96-99.

6 Shepherd J, Krauss RM: Pathophysiology of triglyceride-rich particles: Metabolism of triglyceride-rich particles. Am J Cardiol 1991;68: 5A-7A.
7 Criqui $\mathrm{MH}$ : Triglycerides and cardiovascular disease. A focus on clinical trials. Eur Heart J 1998;19:A36-A39.

8 Hodis HN, Mack WJ: Triglyceride-rich lipoproteins and progression of atherosclerosis. Eur Heart J 1998;19:A40-A44.

9 Gaddi A, Cicero AFG, Wani FO, Dormi A, Pasquarelli V, D'Addato S: The realization of a project aimed at reducing the plasmatic lipid level in a large Italian rural population improves the mean calcium daily intake: The Brisighella Study. Eur J Clin Nutr 2001;55:97106.

10 Caslake MJ, Packard CJ: The use of ultracentrifugation for the separation of lipoproteins; in Rifai N, Warnick R, Dominiczak MH (eds): Handbook of Lipoprotein Testing. Washington, American Association of Clinical Chemistry Press, 1997, pp 509-529.
11 Mercuri M, Bond M, Sirtori CR, Veglia F, Crepaldi G, Ferugli FS, Descovich G, Ricci G, Rubba P, Mancini M, Gallus G, Bianchi G, D'Alo G, Ventura A: Pravastatin reduces carotid intima-media thickness progression in an asymptomatic hypercholesterolemic mediterranean population: The Carotid Atherosclerosis Italian Ultrasounds Study. Am J Med 1996; 101:627-634.

12 Cullen P: Evidence that triglycerides are an independent coronary heart disease risk factor. Am J Cardiol 2000;86:943-949.

13 Expert panel on detection, evaluation and treatment of high blood cholesterol in adults. Executive summary of the third report of the National Cholesterol Education Program (NCEP) expert panel on detection, evaluation and treatment of high blood cholesterol in adults (Adult Treatment Panel III). J Am Med Assoc 2001;286:2486-2496. 